\title{
TREATMENT OF DYSREACTION DISEASES WITH NITROGEN MUSTARDS*
}

\author{
BY \\ C. JIMENEZ DÍAZ \\ Director of the University Medical Clinic, Madrid
}

The Dysreaction Diseases

It is many years since we first began (Jiménez Díaz, 1920) the clinical study of certain diseases for which the name allergic has since been generally accepted. We studied the sensitizing factors in Spain and demonstrated sensitization to various substances, some reported beforehand and others discovered in the course of our studies.

Treatment of Asthma.-Many cases of bronchial asthma, which resisted every allaying measure, improved and apparently recovered or remained free from attack. As time went by we centred our attention more and more on the failures. Hurst (1943) commented humorously that he, himself an asthmatic patient, had seen that all the methods commended for the treatment of asthma were successful in 80 per cent. of cases and that this percentage is the same for iodides, desensitization, and allergen-free chambers. No doubt the rates of failure are greater than those generously admitted by Hurst, and are matter for serious thought. If the asthmatic patients are isolated from the allergens deemed harmful, why do the crises recur as if new sensitization had supervened ? and why is it that, if certain disregarded reacting factors change, these allergens are no longer harmful ? One of the most noteworthy examples is high fever, which overcomes the asthmatic status even in patients in an allergenic environment, e.g. a patient sensitized to fungi, a condition still persisting at his home by the sea. This observation worried us, and we studied its possible mechanism hoping to find a common factor which would have more certain and protracted results. We were able to show that artificially-induced fevers inhibited anaphylactic shock (Arjona and others, 1944), but the reason escaped us. We then thought that certain enzymes might be inactivated at a high temperature, and considered the fact that the activity of cholinesterase is attenuated over $38^{\circ} \mathrm{C}$. We studied the plasma and urine of patients with allergic diseases and demonstrated the excretion of a stable acetylcholine ester in the urine during crises of migraine (Jiménez Díaz and others, 1941; Lorente and Jiménez Díaz, 1943). At that time acetylase was unknown and it was believed that cholinesterase had a double effect (the formation and destruction of acetylcholine) so that in our case we thought perhaps this " cholinergic paroxysm" (the attack of migraine) resulted from the excessive production of these esters, which would be suppressed when they were inactivated by the raised temperature. However, we were unable to demonstrate an over-production of such substances in attacks of bronchial asthma.

Nucleus of Dysreaction.-It is evident, nevertheless, that different circumstances can mitigate or even abolish the attacks in asthmatic patients. We pointed out (Arjona and others, 1944) the " reversible nature " of asthmatic conditions even in cases in which, on account of its unremitting quality and secondary effects, an organic change seemed

* Read to the Heberden Society at the West London Hospital, March 7, 1951. 
obvious. We reported cases in which asthma disappeared because of jaundice, myxoedema, or the onset of nephritis, and still seeking a common factor, suggested that it might be ascribed to the cholesterol in plasma. This idea seemed strengthened by the concurrent demonstration of low blood cholesterol figures in the majority of cases of unremitting infectious asthma. Treatment with injections of cholesterol gave no results, even if the blood cholesterol did not in fact rise, and transfusion of jaundice plasma was not effective in asthma. Hence the problem remained unsolved, but it was evident (Jiménez Díaz, 1944) that sensitizations, besides pollinosis, have an adjunctive value in bronchial asthma. The main point of so-called allergic diseases is the "nucleus of dysreaction". Only when this is known and may be subjected to modification, we said, will it be possible to overcome asthma whether sensitizing agents are present or not.

Reversibility of Rheumatoid Arthritis.-Parallel to these observations on asthma are those of Hench (1949) on the " potential reversibility of rheumatoid arthritis ", another disease whose aetiology remains obscure, but in the genesis of which the role played by the "hyperergic reaction" is quite obvious. Hench pointed the effects of pregnancy, jaundice, etc., and his discovery (Hench and others, 1949) gave the means of modifying certain diseases by changing the "reaction". The effects of compound E and ACTH do not depend upon the existence of primary dysfunction of the adrenals and pituitary gland, or upon an excessive consumption of these hormones in such patients, but could be explained by the change which they bring about in the organic reaction against sundry stimuli. The discovery of Hench and his colleagues was made at a time when new discoveries in the field of pathology have strengthened the idea of a common dysreactional ground in diseases aetiologically and pathologically different.

Diseases of Adaptation against Stress.-The studies of Selye (1950a, b) on the " diseases of adaptation against stress" suggest the varying consequence of stress through the reaction of the peripheral-hypothalamus-pituitary-adrenal system. Stress provokes the production of ACTH and hormone $\mathrm{X}$ in the anterior lobe of the pituitary gland, and inhibits the production of other less essential hormones (gonado-somato- and thyrotrophic) in organic defence. ACTH arouses the production of glucocorticoids, which stimulate gluconeogenesis, lympholysis, and reticulo-endothelial reaction, and inhibit the histaminergic reaction and fibrosis; the $\mathrm{X}$ hormone promotes the formation of mineralcorticoids which act antagonistically, furthering fibrinoid degeneration, hyalinosis, and the formation of granulomata. This is not the proper time for a critical evaluation of Selye's thesis, which may not be admissible in its entirety but has undoubtedly underlined the role of stress and endocrine reaction in the genesis of a large group of diseases.

Collagen Diseases. - The studies of Klinge (1933), Vaubel (1932), and Rich and Gregory (1943a, b) have shown how to obtain lesions by injecting heterologous proteins which characterize various diseases, such as rheumatoid arthritis, disseminated lupus erythematosus, periarteritis nodosa, scleroderma, dermatomyositis, and Buerger's disease. The concept of " collagen diseases " having been established by Klemperer and others (1941), all these processes would fall within these conditions; although it should be noted that the alterations of collagen are not always due to an allergic mechanism and that the lesions are not always equivalent. Thus from different starting points a common nucleus of dysreaction has been reached and accepted in this group of diseases in which a " potential reversibility" exists.

\section{Effects of Cortisone and ACTH and of the Nitrogen Mustards}

The mechanism whereby cortisone and ACTH modify this common dysreactional factor is little understood at present. It seems likely, however, that its action must in part be connected with changes in antibody formation. Collagen disease in conditions arising from sensitization to foreign proteins might 
be explained by local precipitation on the tissue of the antigen-antibody complex (Altshuler and Angevine, 1949; Schwab and others, 1950). We have shown the direct precipitation of albumins in the kidney in nephritis by nephrotoxic serum (Roda and others, 1949); and Heymann and others (1950) showed a local deposit of labelled antibody in damaged tissue.

Dougherty and White (1943) demonstrated an increase of phagocytosis, gammaglobulin, and antibodies by adrenal and pituitary hormones, possibly connected with lympholysis. Other authors have not confirmed the stimulation of antibodies by ACTH (Eisen and others, 1947; Herbert and de Vries, 1949), but lympholysis is constantly found (Hills and others, 1948; Thorn and others, 1948, 1950). Moreover, the role of the lymphocytes in antibody formation has been stressed by many authors (Sabin, 1939; McMaster and Hudack, 1935; Dougherty and others, 1945). On the other hand, Green (1950) has connected the therapeutic effect of ACTH with its antimitotic action.

Owing to the difficulties of obtaining sufficient amounts of ACTH and cortisone, we began to experiment with nitrogen mustards in the treatment of these allergic diseases for the following reasons:

(1) They produce leucopenia and lympholysis (Pappenheimer and Vance, 1920; Gilman and Philips, 1946).

(2) They have an antimitotic effect.

(3) There is a similarity, though not identity (since they can be produced even when the adrenals are absent), between the action of nitrogen mustards and the " reaction of alarm " (Karnofsky and others, 1948).

(4) They cause adrenal hyperplasia and increased rate of excretion of 17-ketosteroids (Betz and others, 1949; Heusghem and Charlier, 1949).

\section{Present Investigations}

In a series of studies on the action of nitrogen mustards we noted that the injection of nitrogen mustards produces an increased excretion of 17-ketosteroids, clearly perceptible hyperplasis of the adrenals, and a checking effect of anaphylactic shock in the sensitized guinea-pig, preventing bronchial asthma experimentally induced by spraying the antigen in a chamber in which the sensitized guinea-pig is kept. These facts coincide with the observations of other authors (Table I). Other instructive facts also came to light, and many phenomena of experimental hypersensitivity were checked by ACTH, cortisone, and nitrogen mustards. Hence the vascular and cardiac valvular lesions induced by injections of heterologous sera and inhibited by ACTH (Seifter and others, 1950) are also inhibited by nitrogen mustards (Dammin and Bukantz, 1949; Forman and others, 1949). Schwab and others (1950) also observed this inhibition and the concurrent suppression of the adsorption of the complement. The phenomenon of Shwartzman is inhibited by ACTH (Soffer and others, 1950), and also by nitrogen mustards (Schlang, 1950). The phenomenon of Arthus, inhibited by cortisone and ACTH (Germuth and Ottinger, 1950), is likewise inhibited by nitrogen mustards (Forman and others, 1949; Dammin and Bukantz, 1949). Formalin-induced arthritis, inhibited by 
TABLE I

PARALLELISM BETWEEN ACTION OF ACTH AND CORTISONE AND OF NITROGEN MUSTARDS

\begin{tabular}{|c|c|c|c|c|c|}
\hline \multirow{2}{*}{\multicolumn{2}{|c|}{ Process }} & \multicolumn{2}{|c|}{ ACTH and Cortisone } & \multicolumn{2}{|c|}{ Nitrogen Mustards } \\
\hline & & Effect & Author and Date & Effect & Author and Date \\
\hline \multicolumn{2}{|l|}{ Lympholisis } & increase & $\begin{array}{l}\text { Hills and others, } \\
1948 \\
\text { Thorn and others, } \\
1948,1950\end{array}$ & increase & $\underset{1946}{\text { Gilman }}$ and Philips, \\
\hline \multicolumn{2}{|c|}{ Adrenal Glands } & $\begin{array}{l}\text { hyper- } \\
\text { plasia }\end{array}$ & - & $\begin{array}{l}\text { hyper- } \\
\text { plasia }\end{array}$ & $\begin{array}{l}\text { Karnofsky and others, } \\
1948 \\
\text { Betz and others, } 1949 \\
\text { Heusghem and } \\
\text { Charlier, } 1949\end{array}$ \\
\hline \multicolumn{2}{|l|}{ Mitosis } & $\begin{array}{l}\text { anti- } \\
\text { mitosis }\end{array}$ & Green, 1950 & $\begin{array}{l}\text { anti- } \\
\text { mitosis }\end{array}$ & - \\
\hline \multicolumn{2}{|c|}{ 17-ketosteroid Excretion } & increase & $\begin{array}{l}\text { Thorn and others, } \\
1948,1950\end{array}$ & increase & $\begin{array}{l}\text { Betz and others, } 1949 \\
\text { Heusghem and } \\
\text { Charlier, 1949 } \\
\text { Jiménez Díaz, 1950 } \\
\text { Jiménez Díaz and } \\
\text { others, 1950a, b }\end{array}$ \\
\hline \multirow{5}{*}{$\begin{array}{l}\text { Experimental } \\
\text { Allergic } \\
\text { Phenomena }\end{array}$} & $\begin{array}{l}\text { Formalin- } \\
\text { induced } \\
\text { arthritis }\end{array}$ & \multirow{5}{*}{$\begin{array}{c}\text { inhibi- } \\
\text { tion }\end{array}$} & Selye, 1949, 1950a, b & \multirow{5}{*}{$\begin{array}{c}\text { inhibi- } \\
\text { tion }\end{array}$} & Meier, 1950 \\
\hline & $\begin{array}{l}\text { Arthus' } \\
\text { phenomenon }\end{array}$ & & $\begin{array}{l}\text { Germuth and } \\
\text { Ottinger, } 1950\end{array}$ & & $\begin{array}{l}\text { Dammin and } \\
\text { Bukantz, } 1949 \\
\text { Forman and others, } \\
1949\end{array}$ \\
\hline & $\begin{array}{l}\text { Shwartz- } \\
\text { man's } \\
\text { phenomenon }\end{array}$ & & $\begin{array}{l}\text { Soffer and others, } \\
1950\end{array}$ & & Schlang, 1950 \\
\hline & \multirow{2}{*}{$\begin{array}{l}\text { Arteritis } \\
\text { and valvular } \\
\text { lesions } \\
\text { induced by } \\
\text { homologous } \\
\text { sera. } \\
\text { Experimental } \\
\text { anaphylactic } \\
\text { asthma }\end{array}$} & & \multirow[t]{2}{*}{$\begin{array}{l}\text { Seifter and others, } \\
1950\end{array}$} & & $\begin{array}{l}\text { Dammin and } \\
\quad \text { Bukantz, } 1949 \\
\text { Forman and others, } \\
\quad 1949\end{array}$ \\
\hline & & & & & $\begin{array}{l}\text { Jiménez Díaz and } \\
\text { others, } 1950 \mathrm{a}, \mathrm{b}, \mathrm{c}\end{array}$ \\
\hline
\end{tabular}

ACTH (Selye, 1949, 1950a, b), is also checked by nitrogen mustards (Meier, 1950). We have seen the checking effect of these substances on anaphylactic shock and, furthermore, on experimental asthma induced in sensitized guinea-pigs. Robson and Duthie (1950) demonstrated a similarity between the action of ACTH and that of nitrogen mustard on the capillary permeability.

Although differences do exist, it is obvious that the effects of nitrogen mustards, ACTH, and cortisone have many points of contact, and that their action is similar as regards the phenomena of shock and immunity. Nitrogen mustard (NH3) 
stimulates adrenal function, but its effect is due not only to this factor, but also to its direct action on antibody formation and antigen-antibody combination, and its precipitation on collagen substances.

Technique.-At first we used the doses applied in Hodgkin's disease, but in some cases leukopenia was too pronounced and symptoms of thrombocytopenic purpura occurred. It was deemed advisable to decrease the dosage and at present we give three or four injections at the most, of 4 to $6 \mathrm{mg}$. each, according to the weight of the body. Injections are given on alternate days by the usual technique for intravenous serum injections. We are at present trying another technique involving smaller doses over a longer period. It is obvious that with time this therapy may be improved, and certain allied compounds (such as naphtilic) may be used by the oral route. Moreover, by changing the chemical structure, more active and less toxic compounds might be found.

Results.-Rheumatoid arthritis, asthma, psoriasis, scleroderma, periarteritis nodosa, Buerger's thrombo-angiitis, and iritis were treated with nitrogen mustard (tri-B-chloroethylamine) with the following results.

(1) Rheumatoid Arthritis.-Up to the present 32 cases have been treated (Jiménez Díaz, 1950; Jiménez Díaz and others, 1950a, b, c). The most regular effect was that on pain which, in every case, improved, and in the majority disappeared entirely. At the same time, the inflammation of the joint and the effusion underwent a striking decrease, which could be shown objectively by direct measurement. This permitted a greater degree of movement; contractions, and particular positions taken to mitigate pain, disappeared. Bed-ridden patients began to move, walk, and use their hands, and in the best cases a striking return to normal occurred. The majority of patients treated were cripples of 5 to 10 years standing, and the improvement was startling. True ankylosis, understandably, was not influenced, but the outstanding part played by the pain, inflammation, and contractions in joint immobilization was clearly seen, and some of the more acute cases without ankylosis made a full recovery. The results (classified in Table II) were as follows:

(i) pronounced leukopenia and lymphopenia were present in the blood;

(ii) the figure for eosinophils fell;

(iii) in contrast with what has been observed with ACTH and cortisone, the sedimentation rate changed very little, if at all (occasionally it increased temporarily, and it decreased slightly in a few cases);

(iv) where fever existed it disappeared;

(v) the excretion of 17-ketosteroids steadily mounted;

(vi) the excretion of uric acid fell at first and rose again afterwards.

(2) Bronchial Asthma.-We have already published our first results in this disease (Arjona and others, 1944). Thirteen cases have been treated up to date (Table III), mostly ones of long standing that had not improved with standard treatments and had been in our department of allergy for a long time. The first case involved a woman who had had protracted attacks for many months and derived only brief respite from aminophyllin and adrenaline. From the first injection she was able to lie down and rest; the condition disappeared after the second injection, and she has remained thus for six months. In promising cases, dyspnoea 
TABLE II

RESULTS OF TREATMENT WITH NITROGEN MUSTARDS IN 32 CASES OF RHEUMATOID ARTHRITIS

\begin{tabular}{|c|c|c|c|c|c|}
\hline Patient & Sex & Result & Patient & Sex & Result \\
\hline $\begin{array}{l}\text { M.M. } \\
\text { C.S. } \\
\text { P.G. } \\
\text { B.S. } \\
\text { M.R. } \\
\text { F.G. } \\
\text { F.S. } \\
\text { J.M. } \\
\text { E.S. } \\
\text { M.B. } \\
\text { L.E. } \\
\text { D.F. } \\
\text { A.N. } \\
\text { M.L. } \\
\text { J.G. } \\
\text { J.P. }\end{array}$ & $\begin{array}{l}\mathbf{F} \\
\mathbf{F} \\
\mathbf{F} \\
\mathbf{M} \\
\mathbf{M} \\
\mathbf{F} \\
\mathbf{M} \\
\mathbf{M} \\
\mathbf{M} \\
\mathbf{F} \\
\mathbf{F} \\
\mathbf{F} \\
\mathbf{F} \\
\mathbf{M} \\
\mathbf{M} \\
\mathbf{M}\end{array}$ & $\begin{array}{l}+++ \\
+++ \\
+++ \\
+ \\
+++ \\
++ \\
+++ \\
+++ \\
++ \\
+++ \\
++ \\
+++ \\
+++ \\
++ \\
++ \\
++ \\
+++\end{array}$ & $\begin{array}{l}\text { J.H. } \\
\text { M.I. } \\
\text { J.C. } \\
\text { J.H. } \\
\text { C.M. } \\
\text { E.C. } \\
\text { M.C. } \\
\text { M.A. } \\
\text { E.B. } \\
\text { S.H. } \\
\text { M.J. } \\
\text { S.M. } \\
\text { M.P. } \\
\text { B.B. } \\
\text { I.S. } \\
\text { A.F. }\end{array}$ & $\begin{array}{l}\mathbf{F} \\
\mathbf{M} \\
\mathbf{F} \\
\mathbf{M} \\
\mathbf{F} \\
\mathbf{M} \\
\mathbf{F} \\
\mathbf{F} \\
\mathbf{F} \\
\mathbf{M} \\
\mathbf{F} \\
\mathbf{F} \\
\mathbf{F} \\
\mathbf{F} \\
\mathbf{F} \\
\mathbf{M}\end{array}$ & $\begin{array}{l}+++ \\
+++ \\
+++ \\
+ \\
++ \\
++ \\
++ \\
+++ \\
+++ \\
+++ \\
+ \\
++ \\
++ \\
+++ \\
+ \\
+++\end{array}$ \\
\hline
\end{tabular}

Eighteen $(56 \cdot 25$ per cent.) +++ Very Good (disappearance of pain, swelling, etc., and recovery of movement, excepting joints with osseous ankylosis). Eight ( 25 per cent.) ++ Good (accentuated decrease of subjective phenomena with evident improvement in movement).

Six (18.75 per cent.) + Poor (little improvement; decrease of pain).

TABLE III

RESULTS OF TREATMENT WITH NITROGEN MUSTARDS IN 13 CASES OF SEVERE INFECTIOUS ASTHMA

\begin{tabular}{c|c|cc}
\hline Patient & Sex & Result & Relapse \\
\hline V.I. & $\mathbf{M}$ & +++ & no \\
A.P. & $\mathbf{F}$ & +++ & no \\
M.G. & $\mathbf{F}$ & +++ & no \\
J.G. & $\mathbf{M}$ & +++ & no \\
F.C. & $\mathbf{M}$ & +++ & no \\
M.A. & $\mathbf{M}$ & ++ & yes \\
R.R. & $\mathbf{M}$ & +++ & no \\
S.H. & $\mathbf{F}$ & ++ & no \\
M.T. & $\mathbf{F}$ & +++ & yes \\
A.S. & $\mathbf{F}$ & +++ & no \\
M.A. & $\mathbf{F}$ & + & - \\
F.M. & $\mathbf{M}$ & & \\
P.N. & & & \\
\hline
\end{tabular}

+++ freed from asthmatic symptoms, ten ( 76.9 per cent.).

++ greatly improved, one $(7.7$ per cent.).

+ no improvement, two (15.4 per cent.).

disappeared after the second injection and, concurrently, objective improvement in auscultation was noticeable together with an improvement of the vital capacity as shown by the spirographic curves. The effect was parallel to the fall in eosinophils per c.mm. The results in asthma were more striking than those observed in rheumatoid arthritis. 


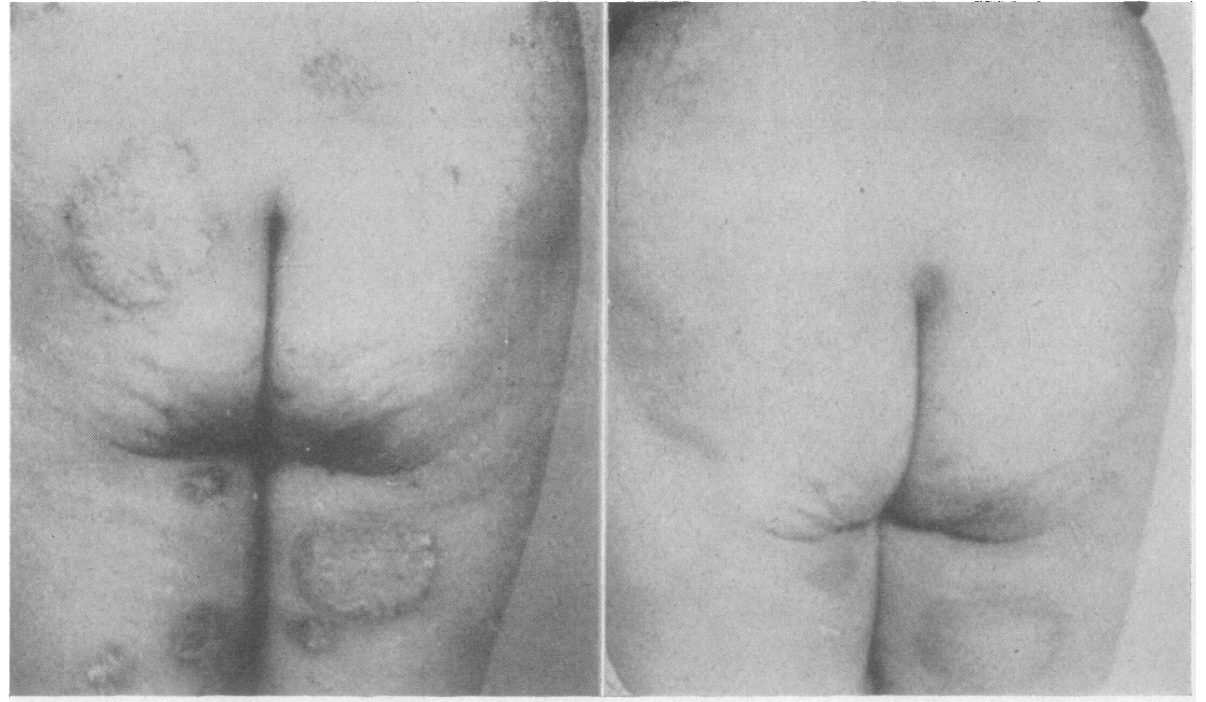

(a) before treatment

(b) after treatment

FigURE.-Effect of nitrogen-mustard therapy in a case of psoriasis.

(3) Psoriasis.-One of our rheumatic patients had large patches of psoriasis. The effect of treatment is shown in the Figure. Orbaneja (1951) has since treated many cases; cutaneous symptoms have disappeared in every instance and, though a relapse occurred in some within a few weeks, in others the improvement has been maintained for 8 months.

(4) Other Conditions.-We treated one female patient with scleroderma and distal arthritis. The hard oedema was reduced, the skin became flexible, and pain was relieved.

Of three cases of thrombo-angiitis, two with persistent phlebitic nodules got rid of them, and the circulation improved in all three.

In one case of severe iritis, the patient had already lost one eye and sight was minimal in the other, with marked pain. When she was treated by my assistant, Dr. Roda, sight became normal in the remaining eye, so that she could read and work under normal conditions, and pain disappeared after the second injection.

\section{Summary}

(1) The author's studies of the reversibility of bronchial asthma by modification of the "nucleus of dysreaction" were in some ways parallel to Hench's observations on the "potential reversibility of rheumatoid arthritis", another disease in which an important role is played by "hyperergic reaction ".

(2) Experiments with the treatment of various allergic diseases with nitrogen mustards were tried, because nitrogen mustard (NH3) had been shown to produce a range of effects somewhat similar to those produced by ACTH and cortisone, and to have a similar action as regards the phenomena of shock and immunity. 
(3) In the majority of 32 cases of rheumatoid arthritis and 13 cases of asthma, considerable improvement occurred. Other conditions which benefited from the treatment were psoriasis, scleroderma, thrombo-angiitis, and iritis.

(4) The author thinks that these first results may open a promising new line of future research.

This work was carried out with the help of Drs. López García, Merchante, and Perianes, on the clinical side; and Drs. Arjona, Aguirre, Perianes, Linazasoro, and Vivanco, on the biochemical and experimental side.

\section{REFERENCES}

Altshuler, C. H., and Angevine, D. M. (1949). Amer. J. Path., 25, 1061.

Arjona, E., Alés, J. M., and Jiménez Díaz, C. (1944). Rev. clin. esp., 15, 18.

Betz, H., Heusghem, C., and Lecomte, J. (1949). Rev. belge Path., 19, 251.

Dammin, G. J., and Bukantz, S. C. (1949). J. Amer. med. Ass., 139, 358.

Dougherty, T. F., Chase, J. H., and White, A. (1945). Proc. Soc. exp. Biol., N.Y., 58, 135.

- and White, A. (1943). 'Ibid., 53, 132.

Eisen, H. N., Mayer, M. M., Moore, D. H., Tarr, R. R., and Stoerk, H. C. (1947). Ibid., 65, 301.

Forman, C., Seifter, J., and Ehrich, W. E. (1949). J. Allergy, 20, 273.

Germuth, F. G., and Ottinger, B. (1950). Proc. Soc. exp. Biol., N.Y., 74, 815.

Gilman, A., and Philips, F. S. (1946). Science, 103, 409.

Green, H. N. (1950). Brit. med. J., 1, 1165.

Hench, P. S. (1949). Annals of the Rheumatic Diseases, 8, 90.

, Kendall, E. C., Slocumb, C. H., and Polley, H. F. (1949). Proc. Mayo Clin., 24, 181.

Herbert, P. H., and de Vries, J. A. (1949). Endocrinology, 44, 259.

Heusghem, C., and Charlier, R. (1949). Rev. belge Path., 19, 339.

Heymann, W., Gilkey, C., and Salehar, M. (1950). Proc. Soc. exp. Biol., 73, 385.

Hills, A. G., Forsham, P. H., and Finch, C. A. (1948). Blood, 3, 755.

Hurst, A. (1943). Brit. med. J., 1, 403.

Jiménez Díaz, C. (1920). “Contribución al estudio de la autointoxicación intestinal.” Madrid.

- (1932). " El asma y otras enfermedades alérgicas." "Madrid.

(1944). “Problemas de la patologia interna", pp. 12-43. Madrid.

(1950). Rev. clin. esp., 37, 410.

Lorente, L., Moran, F., and Scimone, I. (1941). Ibid., 3, 417.

- (1942). Ibid., 7, 248.

Merchante, A., Perianes, J., López García, E., and Puig Leal, J. (1950a). Ibid., 38, 261.

, - - - - - - (1950b). Helv. med. Acta, 17, 583.

_- Perianes, J., Merchante, A., Lahoz, C., Barrantes, V., and Lahoz, F. (1950c). Rev. clín. esp., $39,239$.

Lorente, L., and Jiménez Díaz, C. (1943). Ibid., 77, 11.

Karnofsky, D. A., Graef, I., and Smith, H. W. (1948). Amer. J. Path., 24, 275.

Klemperer, P., Pollack, A. D., and Baehr, G. (1941). Arch.'Path., Chicago, 32, 569.

Klinge, F. (1933). Ergebn. allg. Path. path. Anat., 27, 1.

McMaster, P. D., and Hudack, S. S. (1935). J. exp. Med., 61, 783.

Meier (1950). Personal communication.

Orbaneja (1951). Rev. clin. esp. In the press.

Pappenheimer, A. M., and Vance, M. (1920). J. exp. Med., 31, 71.

Rich, A. R., and Gregory, J. E. (1943a). Bull. Johns Hopk. Hosp., 72, 65.

- (1943b). Ibid., 73, 465.

Robson, H. N., and Duthie, J. J. R. (1950). Brit. med. J., 2, 971.

Roda, E., Jiménez Díaz, C., and Linazasoro, J. M. (1949). Bull. Inst. med. Res., Madr., $2,179$.

Sabin, F. R. (1939). J. exp. Med., 70, 67.

Schlang, H. A. (1950). Proc. Soc. exp. Biol., N.Y., 74, 749.

Schwab, L., Moll, F. C., Hall, T., Brean, H., Kirk, M., Hawn, C., Van Zandt, and Janeway, C. A. (1950). J. exp. Med., 91, 505.

Seifter, J., Ehrich, W. E., Begany, A. J., and Warren, G. H. (1950). Proc. Soc. exp. Biol., N. Y., 75, 337.

Selye, H. (1949). Brit. med. J., 2, 1129. (1950a). Ibid., 1, 203. (1950b). Ibid., 1, 1383 .

Soffer, L. J., Shwartzman, G., Schneirson, S. S., and Gabrilove, J. L. (1950). Science, 111, 303.

Thorn, G. W., Forsham, P. H., Frawley, T. F., Hill, S. R., Roche, M., Staehelin, D., and Wilson, D. L. (1950). New Engl. J. Med., 242, 783.

$\longrightarrow$, Prunty, F. T. G., and Hills, A. G. (1948). J. Amer. med. Ass., 137, 1005.

Vaubel, E. (1932). Beitr. path. Anat., 89, 374. 


\section{Traitement des "Maladies de Dysréaction" par la Moutarde Azotée \\ RÉSUMÉ}

(1) Les études de l'auteur sur la reversibilité de l'asthme bronchique par la modification du " noyau de dysréaction" ont été paralleles aux observations de Hench sur la "reversibilité potentielle de l'arthrite rhumatismale ", une autre maladie dans laquelle la réaction hyperergique joue un rôle important.

(2) En partant de la similarité de certains effets des moutardes azotées, de l'ACTH et de la cortisone, ainsi que de la similarité d'action de ces substances dans les phénomènes de choc et d'immunité, on a traité, à titre expérimental, plusieurs maladies allergiques par des moutardes azotées.

(3) Dans la plupart des 32 cas d'arthrite rhumatismale et dans 13 cas d'asthme on a obtenu une amélioration considérable. Des résultats favorables de ce traitement on été observés également dans le psoriasis, la sclérodermie, la thrombo-angéite et dans l'irite.

(4) L'auteur considère que ces premiers résultats ne sont qu'un encouragement aux recherches ultérieures.

\section{Tratamiento de "Enfermedades de Disreacción" con Mostaza Nitrogenada \\ RESUMEN}

(1) Los estudios del autor acerca de la reversibilidad del asma bronquial por modificación del núcleo de disreacción han sido paralelos a las observaciones de Hench sobre la reversibilidad potencial de la artritis reumatoide, otra enfermedad en la que la reacción hiperérgica juega un importante papel.

(2) Se ha realizado experiencia sobre el tratamiento de algunas enfermedades alérgicas con mostaza nitrogenada, partiendo de la similaridad entre muchos de los efectos de esta droga con los de la ACTH y la cortisona, principalmente en relación con los fenómenos de choque e inmunidad.

(3) Se han obtenido mejorías, cuya frecuencia se menciona en el texto, en algunas ocasiones impresionantes, en 32 casos de artritis reumatoide y 13 casos de asma. También se han visto beneficios en casos de esclerodermia, trombo-angitis, iritis y psoriasis.

(4) El autor considera que estos primeros resultados constituyen solamente un horizonte prometedor para el futuro. 